\title{
Effects of frictional properties of quartz and feldspar in the crust on the depth extent of the seismogenic zone
}

\author{
Koji Masuda $^{1 *}$, Takashi Arai ${ }^{1,2}$ and Miki Takahashi ${ }^{1}$
}

\begin{abstract}
The depth extent of the crustal seismogenic zone is closely related to the size of earthquakes. The mechanisms that control the depth of the lower transition of the seismogenic zone are important issues in seismology and disaster mitigation. Laboratory studies have shown that the mechanism of earthquake nucleation is controlled by the frictional properties of fault materials. We measured the velocity dependences of the steady-state friction of quartz and feldspar, two major components of crustal rocks, under dry and wet conditions at temperatures up to $600^{\circ} \mathrm{C}$. In the presence of water, the temperature range over which the velocity dependence of steady-state friction was negative was wider for feldspar than for quartz, thus indicating that the temperature range of earthquake nucleation is wider for feldspar than for quartz. Considering that temperature increases with depth, our findings indicate that the material properties of feldspar likely play a dominant role in limiting the depth extent of the seismogenic zone.
\end{abstract}

Keywords: Fault friction, Quartz, Feldspar

\section{Introduction}

The magnitude of earthquakes is directly related to the subsurface depth range over which they nucleate, that is, the depth extent or thickness of the seismogenic zone. Thicker seismogenic zones produce higher magnitude earthquakes that can have disastrous consequences for human society. Earthquakes nucleate only in the parts of faults that lie within the seismogenic zone. Understanding what determines the depth extent of the seismogenic zone, especially the depth of the lower stability transition, is a critical issue in seismology. For crustal faults, the seismogenic zone typically extends from 3 to $4 \mathrm{~km}$ to $15-20 \mathrm{~km}$ depth. The shallow parts of faults are commonly within poorly consolidated near-surface sediments that provide an energy sink that stops propagation of earthquake ruptures. In the shallow parts of faults, the upper transition of the seismogenic zone is less variable than in the lower parts; here, we concentrated our

\footnotetext{
* Correspondence: koji.masuda@aist.go.jp

${ }^{1}$ Geological Survey of Japan, National Institute of Advanced Industrial Science and Technology (AIST), Central 7, 1-1-1 Higashi, Tsukuba 305-8567, Japan

Full list of author information is available at the end of the article
}

attention on the lower transition. The depth of the lower limit of the stability transition typically depends on the temperature at which the micro-mechanics of friction change from elastic-brittle deformation to crystal plasticity. The temperature at which this transition occurs for crustal faults is about $300^{\circ} \mathrm{C}$, which corresponds to the onset of plasticity of quartz, the most ductile of the major minerals in granite (e.g., Scholz 1998). However, the depth of this transition varies considerably, which means that it cannot be explained by the temperature dependence of quartz alone. For example, Katayama et al. (2015) showed that aqueous fluids change the mineralogy at the plate interface by producing clay minerals, suggesting that hydration reactions affect rupture processes at seismogenic depths. Thus, the depth of the lower stability transition is likely influenced by the material properties of the local crustal rocks. Quartz and feldspar are particularly common crustal minerals and are therefore of particular interest. A simple model of the seismogenic zone, one that depends on the material properties of its component materials, is a useful first approximation of its large-scale behavior. The idealized conditions used in models and the 
laboratory are seldom met in nature, so models must be used with care.

Laboratory-derived rate and state friction laws have provided the basis for models that successfully explain the processes on fault planes and the relationship of earthquake nucleation and stability (Dieterich 1979, 1981, 2009; Marone 1998; Scholz 1998). The material properties of crustal rocks are the main determinants of their stability, and those properties are dependent on environmental conditions such as temperature, pressure, and the presence of fluids. All real contact surfaces are uneven, such that they touch at only a few points or asperities. Following the initiation of sliding on a pristine rock surface, friction will eventually evolve to steady-state friction as gouge develops (Scholz, 2019). Many laboratory studies have analyzed the velocity dependence of the steady-state friction of gouge at temperatures equivalent to those of the seismogenic zone, for example, for gouge derived from granite (Blanpied et al. 1995, 1998; Lockner et al. 1986), quartz (Chester and Higgs 1992), gabbro (He et al. 2007), and serpentine (Takahashi et al. 2011). Blanpied et al. (1995) found that velocity weakening appeared in granite gouge between 100 and $300^{\circ} \mathrm{C}$ under wet conditions. Velocity weakening has been observed for other materials in several experiments under wet conditions. For example, Chester and Higgs (1992) showed experimentally that variations in the frictional behavior of ultrafine quartz gouge can be understood in terms of a change in the dominant mechanisms of slip, such as the transition from cataclastic slip to solution-precipitation-aided cataclastic flow. Because there is little published information on the frictional properties of the feldspar group of minerals, which are dominant minerals in the crust, neither the temperature (depth) dependence of frictional stability nor the lower limit of the seismogenic zone are well understood. Analyses of the frictional properties of feldspar and quartz, the dominant minerals in crustal rocks, have an important role to play in understanding the depth extent of the seismogenic zone.

In this study, we investigated the velocity dependence of steady-state friction of both quartz and feldspar gouge under dry and wet conditions at temperatures relevant to the seismogenic zone (from room temperature to $600^{\circ} \mathrm{C}$ ). We found clear differences in the temperature ranges at which quartz and feldspar are unstable. Based on the velocity dependence of steady-state friction, which controls the seismic or aseismic behavior of crustal material, we provide here laboratory evidence of the influence of the material properties of quartz and feldspar on the depth extent of the seismogenic zone.

\section{Methods/experimental}

We carried out a series of frictional sliding experiments in a gas medium, high-pressure, and high-temperature triaxial deformation apparatus (Masuda et al. 2002) (Fig. 1). Sliding experiments using ground quartz and feldspar "gouge" samples at constant temperatures were conducted under dry conditions at a confining pressure of $150 \mathrm{MPa}$ and under wet conditions at a confining pressure of $200 \mathrm{MPa}$ with pore-water pressure of $50 \mathrm{MPa}$; the pressure conditions for the wet and dry conditions were effectively the same. Confining and pore pressures were provided by Ar gas and distilled water, respectively, and were controlled by independent servo-control systems. Thirty experiments were performed at temperatures from room temperature $\left(20^{\circ} \mathrm{C}\right)$ to $600^{\circ} \mathrm{C}$ (Table 1). Sample temperatures were controlled by two-zone furnaces that were servo-controlled by the outputs from thermocouples placed at the top and bottom of the sample. The sample configuration was the same as that used by Takahashi et al. $(2007,2011)$. For each experiment, a layer

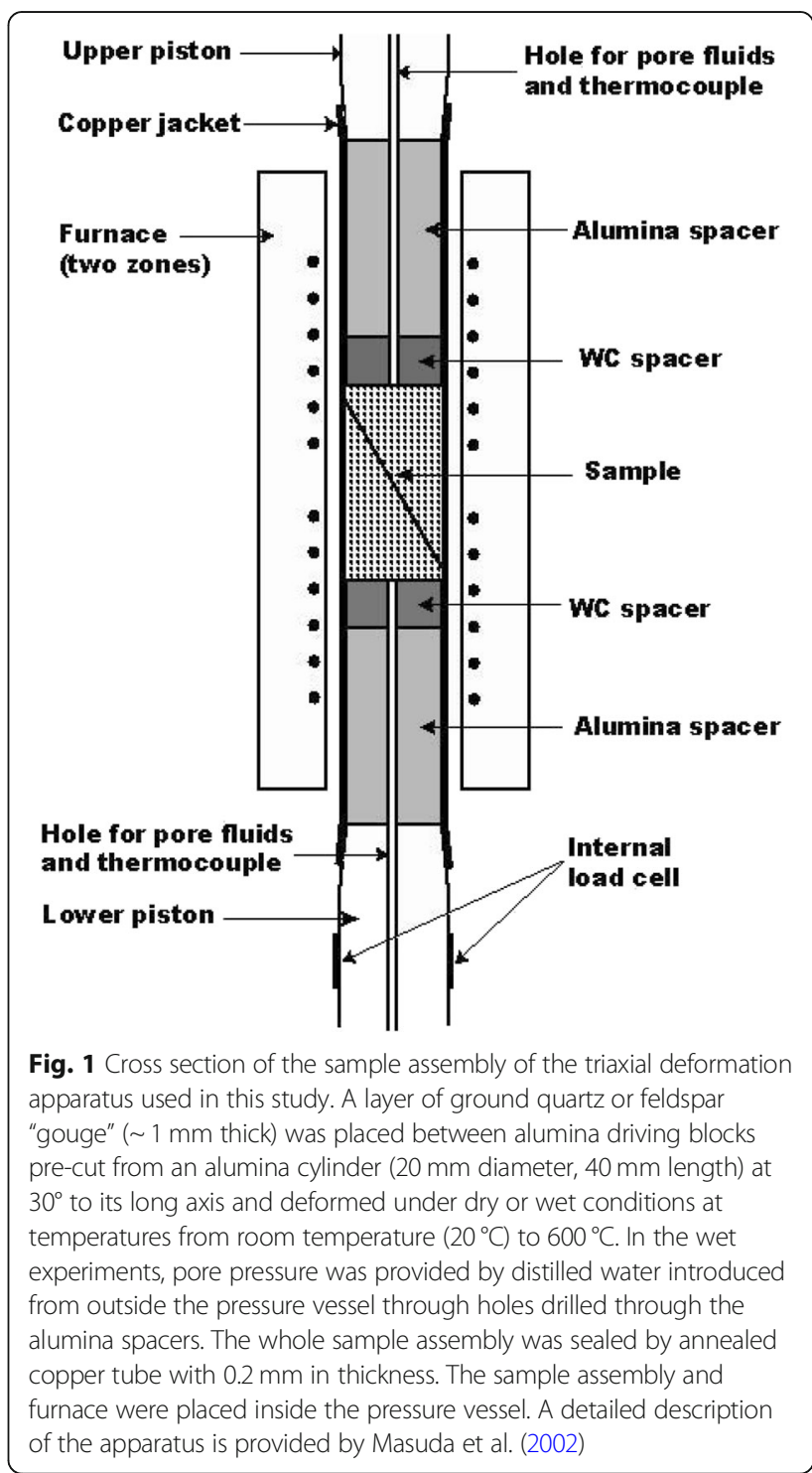


Table 1 Experimental conditions and results

\begin{tabular}{|c|c|c|c|c|c|c|c|c|c|}
\hline Run ID & Mineral & Average grain size & Dry/wet ${ }^{a}$ & $\mathrm{~T}\left({ }^{\circ} \mathrm{C}\right)$ & Coefficient of friction, $\mu$ & Error $^{\mathrm{b}} \mu$ & $a-b$ & Error $^{b} a-b$ & Load cell ${ }^{c}$ data used \\
\hline QCD020 & Quartz & $250 \mu \mathrm{m}$ & Dry & 20 & 0.6006 & 0.0014 & -0.00034 & 0.00008 & I \\
\hline QFD200 & Quartz & $5 \mu \mathrm{m}$ & Dry & 200 & 0.6641 & 0.0045 & 0.00093 & 0.00005 & 1 \\
\hline QCD200 & Quartz & $250 \mu \mathrm{m}$ & Dry & 200 & 0.5502 & 0.0003 & 0.00265 & 0.00007 & 1 \\
\hline QFD300 & Quartz & $5 \mu \mathrm{m}$ & Dry & 300 & 0.6213 & 0.0040 & 0.00490 & 0.00004 & । \\
\hline QFD400 & Quartz & $5 \mu \mathrm{m}$ & Dry & 400 & 0.6395 & 0.0048 & 0.00193 & 0.00007 & 1 \\
\hline QCD400 & Quartz & $250 \mu \mathrm{m}$ & Dry & 400 & 0.6497 & 0.0004 & 0.00560 & 0.00006 & I \\
\hline QCD600 & Quartz & $250 \mu \mathrm{m}$ & Dry & 600 & 0.6666 & 0.0008 & 0.00562 & 0.00013 & 1 \\
\hline QFW100 & Quartz & $5 \mu \mathrm{m}$ & Wet & 100 & 0.6555 & 0.0044 & 0.00421 & 0.00003 & O \\
\hline QFW200 & Quartz & $5 \mu \mathrm{m}$ & Wet & 200 & 0.6254 & 0.0040 & 0.00132 & 0.00005 & 1 \\
\hline QFW300 & Quartz & $5 \mu \mathrm{m}$ & Wet & 300 & 0.6718 & 0.0046 & -0.00122 & 0.00003 & I \\
\hline QFW350 & Quartz & $5 \mu \mathrm{m}$ & Wet & 350 & 0.6383 & 0.0056 & 0.00956 & 0.00003 & O \\
\hline QFW400 & Quartz & $5 \mu \mathrm{m}$ & Wet & 400 & 0.6741 & 0.0008 & 0.00983 & 0.00011 & $\mathrm{O}$ \\
\hline QFW500 & Quartz & $5 \mu \mathrm{m}$ & Wet & 500 & 0.6983 & 0.0012 & 0.01144 & 0.00007 & $\mathrm{O}$ \\
\hline QFW600 & Quartz & $5 \mu \mathrm{m}$ & Wet & 600 & 0.6712 & 0.0014 & 0.00453 & 0.00011 & I \\
\hline FD020 & Feldspar & $50 \mu \mathrm{m}$ & Dry & 20 & 0.6444 & 0.0062 & 0.00184 & 0.00009 & 1 \\
\hline FD100 & Feldspar & $50 \mu \mathrm{m}$ & Dry & 100 & 0.6682 & 0.0016 & 0.00309 & 0.00005 & $\mathrm{O}$ \\
\hline FD200 & Feldspar & $50 \mu \mathrm{m}$ & Dry & 200 & 0.6567 & 0.0066 & 0.00070 & 0.00021 & 1 \\
\hline FD300 & Feldspar & $50 \mu \mathrm{m}$ & Dry & 300 & 0.6562 & 0.0058 & 0.00173 & 0.00013 & 1 \\
\hline FD350-1 & Feldspar & $50 \mu \mathrm{m}$ & Dry & 350 & 0.6673 & 0.0004 & 0.00186 & 0.00009 & 1 \\
\hline FD350-2 & Feldspar & $50 \mu \mathrm{m}$ & Dry & 350 & 0.5314 & 0.0003 & 0.00152 & 0.00007 & I \\
\hline FD400 & Feldspar & $50 \mu \mathrm{m}$ & Dry & 400 & 0.6427 & 0.0061 & 0.00591 & 0.00042 & I \\
\hline FD600 & Feldspar & $50 \mu \mathrm{m}$ & Dry & 600 & 0.6313 & 0.0063 & 0.00142 & 0.00036 & I \\
\hline FW100 & Feldspar & $50 \mu \mathrm{m}$ & Wet & 100 & 0.6819 & 0.0054 & 0.00236 & 0.00003 & $\mathrm{O}$ \\
\hline FW200 & Feldspar & $50 \mu \mathrm{m}$ & Wet & 200 & 0.7590 & 0.0027 & -0.00495 & 0.00014 & I \\
\hline FW250 & Feldspar & $50 \mu \mathrm{m}$ & Wet & 250 & 0.6919 & 0.0058 & -0.00614 & 0.00005 & $\mathrm{O}$ \\
\hline FW300-1 & Feldspar & $50 \mu \mathrm{m}$ & Wet & 300 & 0.6516 & 0.0079 & -0.01304 & 0.00041 & 1 \\
\hline FW300-2 & Feldspar & $50 \mu \mathrm{m}$ & Wet & 300 & 0.6501 & 0.0064 & -0.00870 & 0.00047 & I \\
\hline FW350 & Feldspar & $50 \mu \mathrm{m}$ & Wet & 350 & 0.7285 & 0.0064 & 0.00435 & 0.00098 & $\mathrm{O}$ \\
\hline FW400 & Feldspar & $50 \mu \mathrm{m}$ & Wet & 400 & 0.7016 & 0.0039 & 0.00498 & 0.00028 & $\mathrm{O}$ \\
\hline FW600 & Feldspar & $50 \mu \mathrm{m}$ & Wet & 600 & 0.7080 & 0.0005 & 0.00455 & 0.00007 & 1 \\
\hline
\end{tabular}

${ }^{\mathrm{a}}$ For the dry experiments, a confining pressure of $150 \mathrm{MPa}$ was applied by using Ar gas; for the wet experiments, a confining pressure of $200 \mathrm{MPa}$ was applied, with pore-water pressure of $50 \mathrm{MPa}$

${ }^{\mathrm{b}}$ The errors of coefficients of friction $\mu$ at the yield point (at displacement of $1.5 \mathrm{~mm}$ in this study) and $(a-b)$ were determined by the fitting errors

${ }^{\mathrm{C}}$ The differential stress on the gouge layer was measured by the internal load cell (I), but for cases where no internal load cell data were available, we used the corrected data of the external load cell $(\mathrm{O})$, see main text for details of this correction

of ground quartz or feldspar about $1.0 \mathrm{~mm}$ thick was sandwiched between two alumina blocks pre-cut at an angle of $30^{\circ}$ to the axis of an alumina cylinder $(20 \mathrm{~mm}$ diameter, $40 \mathrm{~mm}$ long) (Fig. 1).

Quartz samples used in this study were two grades of commercially available ground silica (US Silica MIN-USIL 5 and SIL-CO-SIL 250) with average grain sizes of $5 \mu \mathrm{m}$ and $250 \mu \mathrm{m}$, respectively, and $\mathrm{SiO}_{2}$ contents of 99.3\% and $97.3 \%$, respectively. The feldspar samples we used were collected from Miyake-Jima Island, Japan, and were composed of more than $99 \%$ albite $\left(\mathrm{NaAlSi}_{3} \mathrm{O}_{8}\right)$. We first crushed the feldspar samples, then sieved the crushed feldspar samples and removed impurities such as zircon to obtain an almost pure albite powder of about $50 \mu \mathrm{m}$ grain size.

To measure the velocity dependence of the frictional properties of the quartz and feldspar samples, after the yield point was reached (where the increase in friction with displacement became constant), axial displacement rates were stepped between $0.5 \mu \mathrm{m} / \mathrm{s}$ and $5.0 \mu \mathrm{m} / \mathrm{s}$ as follows (Fig. 2). An initial axial displacement rate of $0.5 \mu \mathrm{m} / \mathrm{s}$ was increased abruptly to $5.0 \mu \mathrm{m} / \mathrm{s}$ (fast stepped), and, in some experiments, it was later reduced from $5.0 \mu \mathrm{m} / \mathrm{s}$ to $0.5 \mu \mathrm{m} / \mathrm{s}$ (slow stepped). We evaluated 


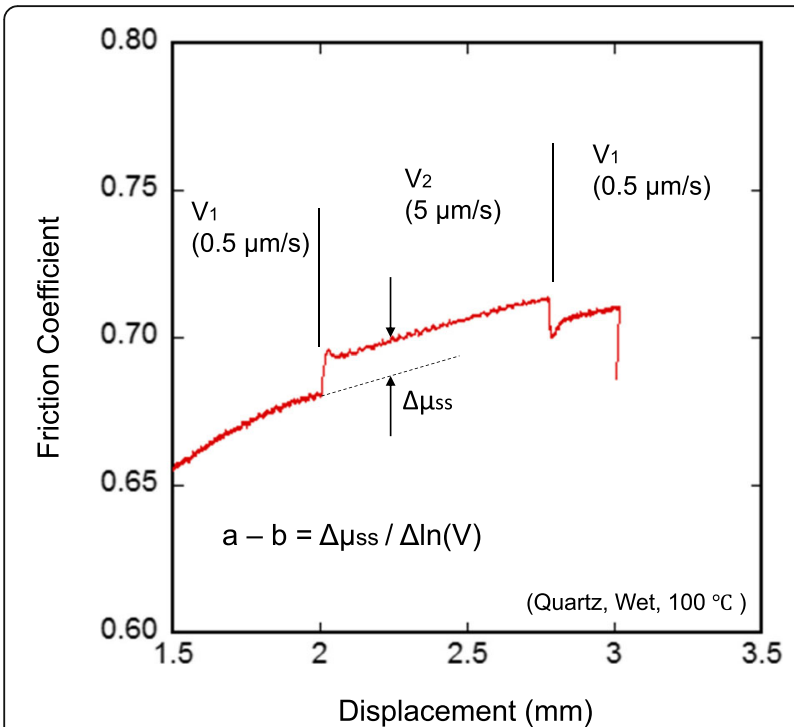

Fig. 2 Enlarged example of a friction curve showing the step changes of slip velocity. The velocity dependence of steady-state friction $(a-b)$, as determined from Eq. (2), is represented by the difference between the parallel steady-state trend lines immediately before and after velocity step changes. In these analyses, we used long trend of the friction curve, not only the portion immediately before and after the step change

the velocity dependence from the fast-stepped portion of the frictional curve. We measured the displacement of the axial loading piston with a linear variable differential transformer (LVDT) placed outside the pressure vessel, and we measured the axial force with an internal load cell located on the loading piston inside the pressure vessel and an external load cell installed outside the pressure vessel. The friction of the gouge layer was calculated from the differential stress measured by the internal load cell. However, in cases where no internal load cell data were available, we used corrected data from the external load cell (Table 1). This correction was achieved by estimating the friction at the O-ring used to seal between the pressure vessel and the loading piston, which we calculated from the outputs of the internal and external load cells. The O-ring was located below the position of the internal load cell (Fig. 1). There was little variation of temperature at the position of the O-ring during our experiments under the various temperature conditions of the sample within the experimental apparatus (cf. Masuda et al. 2006). The frictional force at the O-ring was almost constant during our experiments (e.g., Noda and Takahashi 2016).

The friction coefficient $\mu$ is defined as shear stress $(\tau)$ normalized by normal stress $\left(\sigma_{\mathrm{n}}\right)$ on the sliding surface as

$$
\mu=\frac{\tau}{\sigma_{n}}=\frac{\sigma_{\text {diff }} \sin (2 \theta)}{2\left(\sigma_{\text {diff }} \sin ^{2}(\theta)+P_{\mathrm{c}}\right)},
$$

where $\sigma_{\text {diff }}$ is the differential stress in the loading direction, $\theta$ is the angle between the sliding surface and the loading direction $\left(30^{\circ}\right.$ in this study), and $P_{\mathrm{c}}$ is the effective confining pressure (constant at $150 \mathrm{MPa}$ in this study). The abrupt step changes in sliding velocity cause systematic variations in the friction coefficient $\mu$, which have been described as the combination of a direct effect and an evolutionary effect (rate and state variable constitutive laws) (Dieterich 1979, 1981, 2009; Marone 1998; Scholz 1998). Here, we do not consider the direct effect, which manifests as a transient frictional response indicated by a distinctive peak on the friction-displacement curve immediately after each change of slip velocity, because our digital recording system may not be able to record such a fast change. Instead, we focus here on changes in the steady-state friction response following the abrupt velocity changes.

The seismic (or aseismic) behavior of a fault is determined by its frictional stability, which depends on the parameter $(a-b)$, which defines the velocity dependence of steady-state friction, the ratio of the change of friction to the change of slip velocity:

$$
\mathrm{a}-\mathrm{b}=\frac{\partial \mu_{\mathrm{ss}}}{\partial[\ln V]}
$$

where $\mu_{\mathrm{ss}}$ is the steady-state friction and $V$ is the sliding velocity. If $(a-b)>0$, the material is said to be velocity strengthening and will always be stable, corresponding to an aseismic region. In the case of velocity weakening, $(a-b)<0$, the material is unstable, corresponding to unstable sliding behavior in a seismic region. We estimated the velocity dependence of steady-state friction $(a-b)$ from the difference between the two parallel trends under the steady-state conditions before and after the step changes of slip velocity (Fig. 2).

\section{Results}

\section{Friction coefficient}

Our results for selected sliding experiments at representative temperatures under both dry and wet conditions are shown in Fig. 3. Ideally, with increasing slip, a sheared layer should eventually attain a steady-state condition with constant shear strength (referred to as friction strength). Our samples reached an almost steady state beginning at slip displacements of about $2.5 \mathrm{~mm}$, but exhibited some degree of slip strengthening throughout the deformation, up to the time at which the seal of the sample assembly was broken. Many previous studies have shown similar slip-strengthening behavior, in particular in experiments using clay or fault gouge samples (e.g., Mizoguchi et al. 2008; He et al. 2013; Morrow et al. 2017). 

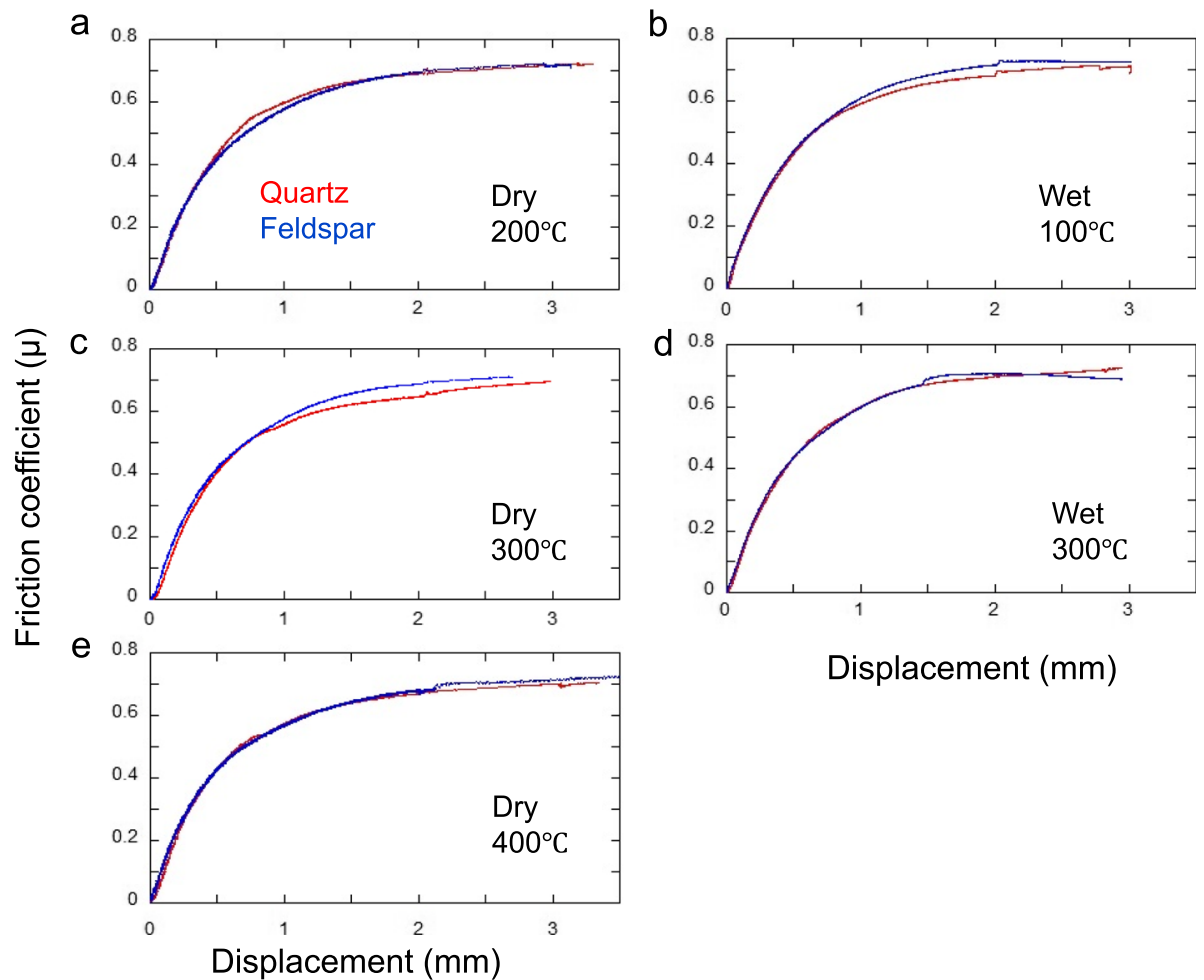

Displacement $(\mathrm{mm})$ displacement of the loading piston for quartz (red curves) and feldspar (blue curves). a Dry samples at $200^{\circ} \mathrm{C} ; \mathbf{b}$ wet samples at $100^{\circ} \mathrm{C} ; \mathbf{c}$ dry samples at $300^{\circ} \mathrm{C}$; $\mathbf{d}$ wet samples at $300^{\circ} \mathrm{C}$; e dry samples at $400^{\circ} \mathrm{C}$

In almost all of our experiments, the friction versus displacement curves changed from an initial elastic loading to steady slip strengthening after displacement of about $1.5 \mathrm{~mm}$. We referred to the displacement of $1.5 \mathrm{~mm}$ as the yield point in this study. The friction coefficient at the yield point was generally in the range 0.6-0.7 (Table 1). The effects of the step changes of slip velocity applied after the yield point was reached are clearly evident in Fig. 3.

In both dry and wet experiments at the same temperatures, the friction coefficient versus displacement curves for both quartz and feldspar samples were almost the same until the yield point was reached (before the slip velocity step was applied), even though the grain sizes of the samples differed (Fig. 3 and Table 1). We assumed, therefore, that the effect of grain size of the samples on the friction curves was minimal and it is not discussed further here.

\section{Velocity dependence of steady-state friction}

Measurements of the velocity dependence of steadystate friction, $(a-b)$ hereafter, as a function of temperature for quartz and feldspar with and without water (Fig. 4 and Table 1) showed markedly different changes with increasing temperature. For the dry samples, $(a-b)$ of both quartz and feldspar were entirely positive, indicating that their frictional properties were stable at all temperatures tested (Fig. 4a). For the wet samples, $(a-b)$ was negative at around $300^{\circ} \mathrm{C}$ for quartz and from about 150 to $350{ }^{\circ} \mathrm{C}$ for feldspar (Fig. 4b). The values of $(a-b)$ of quartz were greater than those of feldspar at almost all temperatures under wet conditions. Similar general features of $(a-b)$ have been reported for granite gouge (e.g., Blanpied et al. 1991). Our results showed that under wet conditions, there was a wider temperature range for which $(a-b)$ of feldspar was negative than was the case for quartz.

\section{Discussion}

The deformation of quartz and feldspar, major components of granitic rocks, has been well documented (e.g., Tullis 2002; Passchier and Trouw 2005). Quartz deforms by brittle mechanisms up to about $300-350{ }^{\circ} \mathrm{C}$, corresponding to crustal depths of around $10-12 \mathrm{~km}$. At greater depths, crystal-plastic mechanisms (creep mechanisms) and diffusion dominate. Feldspar is different because of the difficulty of dislocation glide and climb (crystal-plastic deformation mechanism). It thus deforms in a brittle manner at temperatures up to $500{ }^{\circ} \mathrm{C}$ and depths of $20-30 \mathrm{~km}$ (Fossen 2016). However, the 
a

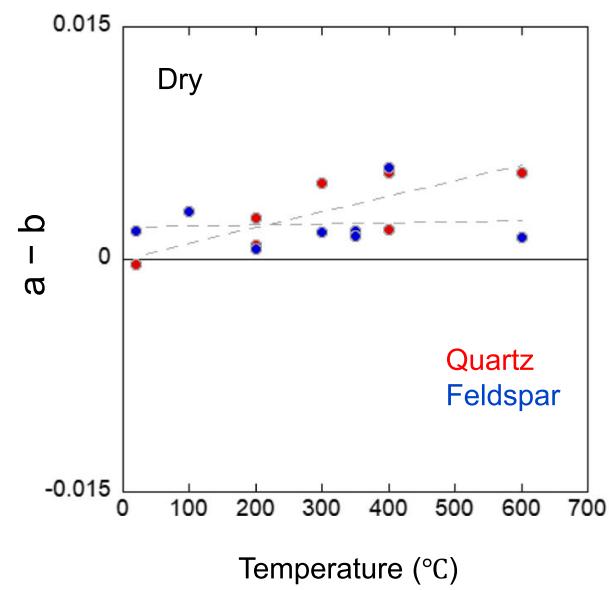

b

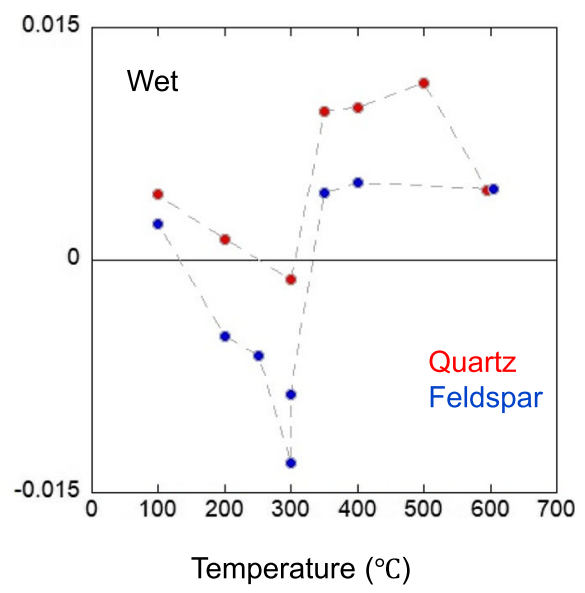

Fig. 4 Velocity dependence of steady-state friction $(a-b)$ as determined from Eq. (2) for quartz and feldspar plotted as a function of temperature. a Dry condition, $P_{c}=150 \mathrm{MPa}$ (Ar gas); $\mathbf{b}$ wet condition, $P_{c}=200 \mathrm{MPa}$ (Ar gas), $P_{\mathrm{p}}$ (pore pressure) $=50 \mathrm{MPa}$ (distilled water)

responses of both quartz and feldspar to frictional forces on fault planes during faulting are not well understood, especially the effect of the presence of water. Our experiments have shown that the frictional characteristics of quartz and feldspar under deep crustal temperature and pressure conditions differ.

\section{Effect of water on velocity dependence of steady-state friction}

The differences of the values of $(a-b)$ that we identified for dry and wet samples of quartz and feldspar demonstrated that the presence of water strongly influence their frictional properties. For both quartz and feldspar, we observed that under wet conditions there were temperature ranges within which $(a-b)$ was negative (corresponding to seismic conditions; Fig. 4), but there was little difference in the frictional coefficient versus displacement curves between the wet and dry samples (Fig. 3). These general trends are similar to those observed in experiments on granite gouge (Blanpied et al. 1991, 1995). Most natural fault zones are fluid-saturated (e.g., Sibson 1992), so we expect that the effect of the presence of water plays an important role in seismogenic processes in the crust. Blanpied et al. (1991) inferred from their experiments on granite gouge that the most likely fluid-related mechanisms are pressure solution of quartz (Rutter and Mainprice 1978) and incongruent pressure solution of feldspar whereby it is dissolved preferentially at stressed interfaces (Beach 1980). Chester and Higgs (1992) and Kanagawa et al. (2000) also suggested that solution transport may be activated by the presence of quartz gouge in a fault.

We suggest that pressure solution occurred in our wet experiments on both quartz and feldspar. SEM images of our samples after the experiments show that rounding of grains occurred during our experiments under wet conditions (Fig. 5), which is supportive of pressure solution taking place. The variations in frictional behavior that we observed can be understood in terms of a change in the dominant mechanisms of slip, such as from cataclastic slip and to solution-precipitation-aided cataclastic flow, as follows. When pressure solution occurred in the wet experiments, dissolved solution was transported to the grain interfaces, where grinding and rounding of the grains of quartz and feldspar occurred, which assisted solution-precipitation-aided cataclastic flow. As a result, frictional resistance was reduced and velocity-weakening behavior was induced. At higher temperatures $\left(>350^{\circ} \mathrm{C}\right)$, the viscosity of the fluids may have increased, resulting in an increase in resistance to slip. The different behaviors of quartz and feldspar may be explained by the different properties of the dissolved solutions. However, our experimental setup did not allow us to analyze the solutions in the course of our experiments, which we have deferred. Solution analysis is remained for the future studies.

\section{Effect of material properties of quartz and feldspar on the} velocity dependence of friction

In almost all of our experiments under wet conditions, the values we obtained for $(a-b)$ were greater for quartz than for feldspar, which indicates that the friction coefficient of quartz becomes larger than that of feldspar with increasing slip velocity. Thus, it is more difficult to initiate slip and cause earthquake nucleation in gouge composed of quartz than in gouge composed of feldspar. Our findings are supported by the work of $\mathrm{He}$ et al. (2013), who found that adding a little quartz to the 


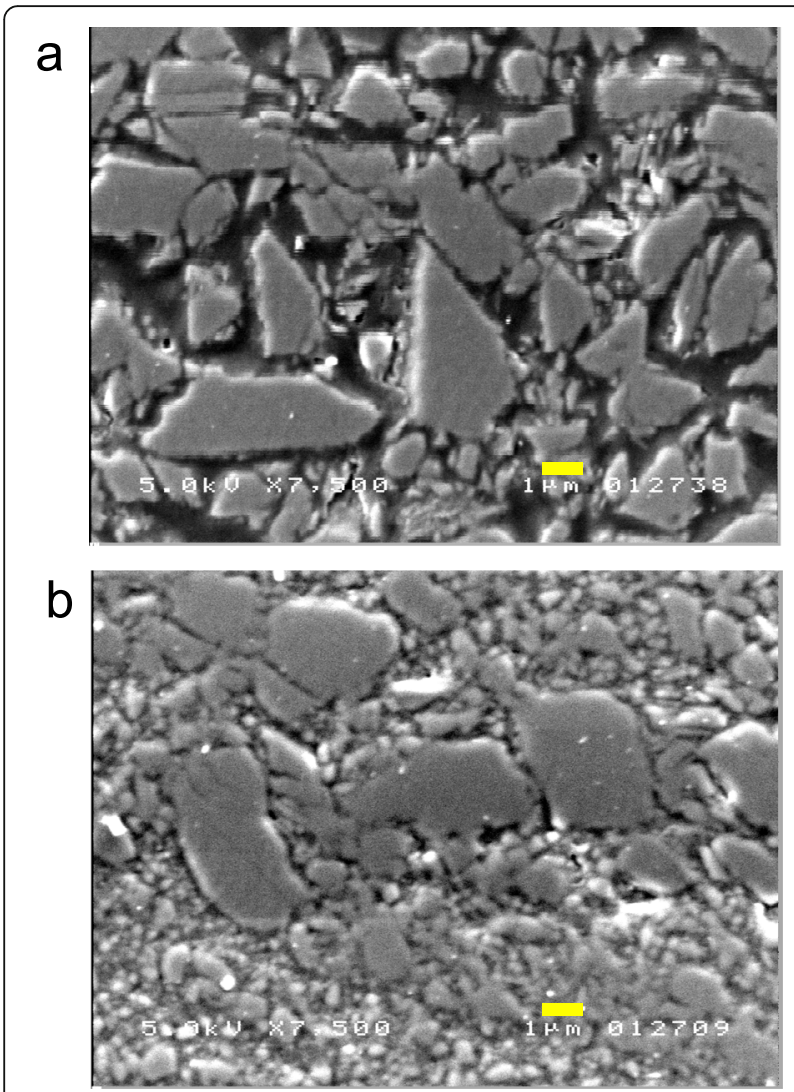

Fig. 5 SEM images of feldspar samples after experiments conducted at $400{ }^{\circ} \mathrm{C}$. a Dry condition; $\mathbf{b}$ wet condition. After the experiments under wet conditions, the feldspar samples were clearly rounded, which is supportive of pressure solution taking place

plagioclase-pyroxene mixture they used to simulate fault gouge had a strong stabilizing effect that led to a transition from velocity weakening to velocity strengthening.

Although both quartz and feldspar are ubiquitous in crustal rocks, there have been few experiments on the frictional behavior of feldspar, probably because pure, fine-grained feldspar aggregates are rare in nature (Tullis 2002). As previously described (in our discussion above of the effect of water on the velocity dependence of steady-state friction), we found that in the presence of water the temperature range over which $(a-b)$ for feldspar was negative was wider than was the case for quartz. Moreover, feldspar is more brittle than quartz under the high-temperature and pressure conditions deep in the crust (e.g., Fossen 2016). The brittle-plastic transition zone of the lower crust may be a region of slow deformation. However, because frictional behavior occurs only within the layers where stress is concentrated at the sliding surface, we consider here the friction-plastic transition. Seismic activity takes place where brittle (frictional) materials move quickly on the fault surface, so material that is more amenable to unstable slip plays a more important role in this region. Our results suggest that under some conditions the influence of feldspar in determining the depth extent of the seismogenic zone in the crust is greater than that of quartz.

Implications for the depth extent of the seismogenic zone To estimate the depth extent of the seismogenic zone in a particular region, regional data are required on the depth-temperature profile, distribution of water, strain rate, and dominant rocks and minerals. The inhomogeneous distribution of earthquakes suggests that the subsurface distribution of the material properties of rocks (i.e., their lithostratigraphy) has a stronger influence on frictional properties at depth than do environmental conditions, such as temperature and strain rate (e.g., Shibazaki et al. 2008).

The availability of data from dense seismic observation networks in and around the Japanese islands allows comparison of precise earthquake hypocenters with subsurface temperature distributions. Hasegawa and Yamamoto (1994) showed that most of the earthquakes in northeastern Japan are confined to the upper $15 \mathrm{~km}$ of the crust, which constitutes the brittle seismogenic zone there. Comparison of those hypocenters to the temperature distribution in the crust, estimated from seismic velocity changes inferred on the basis of seismic tomography, shows a clear correspondence of the lower limit of the seismogenic zone with the 350 to $400{ }^{\circ} \mathrm{C}$ isotherm (Hasegawa and Yamamoto 1994). This temperature range corresponds better to the transition from brittle deformation to plastic behavior of feldspar than to that of quartz.

\section{Conclusions}

The material properties of quartz and feldspar that we determined indicate that feldspar is more likely than quartz to be the major determinant of the depth of the lower transition of the seismogenic zone. Although feldspar is one of the most abundant mineral components of the earth's crust, it does not necessarily follow that the most abundant mineral controls fault movement at depth. Moreover, we tested only albite among the feldspar group of minerals, and those tests were under a limited set of experimental conditions. For example, we used shorter displacements and faster strain rates than what occur in nature, which may have imposed limitations on our results. However, our study of the frictional properties of the two most abundant minerals in the earth's crust provides a conceptual model for laboratorybased mineralogical investigations of the depth extent of the seismogenic zone. 


\section{Acknowledgements}

We thank Tomoaki Sumii for contributing the sample preparation for feldspar for this study. The constructive reviews of two anonymous reviewers and Editor Prof. Yuji Yagi were very helpful in improving the manuscript.

\section{Authors' contributions}

KM designed the study, conducted the experiments, and analyzed the data. TA and MT conducted the experiments and data analysis. All authors contributed to the preparation of the manuscript. All authors read and approved the final manuscript.

\section{Funding}

This work was supported by Management Expenses Grants from the Geological Survey of Japan, National Institute of Advanced Industrial Science and Technology (AIST).

\section{Availability of data and materials}

The datasets used and/or analyzed during the current study are available from the corresponding author on reasonable request.

\section{Competing interests}

The authors declare that they have no competing interests.

\section{Author details}

${ }^{1}$ Geological Survey of Japan, National Institute of Advanced Industrial Science and Technology (AIST), Central 7, 1-1-1 Higashi, Tsukuba 305-8567, Japan. ${ }^{2}$ Present address: National Institute of Technology and Evaluation (NITE), 2-49-10 Nishihara, Shibuya-ku, Tokyo 151-0066, Japan.

\section{Received: 20 September 2018 Accepted: 8 July 2019}

\section{Published online: 19 July 2019}

\section{References}

Beach A (1980) Retrogressive metamorphic processes in shear zones with special reference to the Lewisian complex. J Struct Geol 2:257-263. https://doi.org/ 10.1016/0191-8141(80)90058-9

Blanpied ML, Lockner DA, Byerlee JD (1991) Fault stability inferred from granite sliding experiments at hydrothermal conditions. Geophys Res Lett 18:609-612. https://doi.org/10.1029/91GL00469

Blanpied ML, Lockner DA, Byerlee JD (1995) Frictional slip of granite at hydrothermal conditions. J Geophys Res 100:13045-13064. https://doi.org/ 10.1029/95JB00862

Blanpied ML, Marone CJ, Lockner DA, Byerlee JD, King DP (1998) Quantitative measure of the variation in fault rheology due to fluid-rock interactions. J Geophys Res 103:9691-9712. https://doi.org/10.1029/98JB00162

Chester FM, Higgs NG (1992) Multimechanism friction constitutive model for ultrafine quartz gouge at hypocentral conditions. J Geophysical Res 97:1859-1870. https://doi.org/10.1029/91JB02349

Dieterich JH (1979) Modeling of rock friction: 1. Experimental results and constitutive equations. J Geophysical Res 84:2161-2168. https://doi.org/ 10.1029/JB084iB05p02161

Dieterich JH (1981) Constitutive properties of faults with simulated gouge. In: Carter NL, Friedman M, Logan JM, Stearns DW (eds) Mechanical behavior of crustal rocks. The Handin volume, geophysical monograph series, vol 24. American Geophysical Union, Washington DC, pp 103-120. https://doi.org/ 10.1029/GM024

Dieterich JH (2009) Applications of rate- and state-dependent friction to models of fault slip and earthquake occurrence. In: Kanamori $\mathrm{H}$ (ed) Earthquake seismology, treatise on geophysics, vol 4, Netherlands, Elsevier, pp 107-129. https://doi.org/10.1016/B978-0-444-53802-4.00075-0

Fossen H (2016) Structural geology, 2nd ed. Cambridge University Press, Cambridge, $\mathrm{p} 510$

Hasegawa A, Yamamoto A (1994) Deep, low-frequency microearthquakes in or around seismic low-velocity zones beneath active volcanoes in northeastern Japan. Tectonophysics 233:233-252. https://doi.org/10.1016/0040-1951(94)90243-7

He C, Luo L, Hao Q-M, Zhou Y (2013) Velocity-weakening behavior of plagioclase and pyroxene gouges and stabilizing effect of small amounts of quartz under hydrothermal conditions. J Geophysical Res 118: 1-23. https://doi.org/10.1002/jgrb.50280
He C, Wang Z, Yao W (2007) Frictional sliding of gabbro gouge under hydrothermal conditions. Tectonophysics 445:353-362. https://doi.org/ 10.1016/j.tecto.2007.09.008

Kanagawa K, Cox SF, Zhang S (2000) Effects of dissolution-precipitation processes on the strength and mechanical behavior of quartz gouge at high-temperature hydrothermal conditions. J Geophysical Res 105:11115-11126. https://doi.org/ 10.1029/2000JB900038

Katayama I, Kubo T, Sakuma H, Kawai K (2015) Can clay minerals account for the behavior of non-asperity on the subducting plate interface? Prog Earth Planetary Sci 2:30. https://doi.org/10.1186/s40645-015-0063-4

Lockner DA, Summers R, Byerlee JD (1986) Effects of temperature and sliding rate on frictional strength of granite. Pure Appl Geophysics 124:445-469. https://doi.org/10.1007/BF00877211

Marone C (1998) Laboratory-derived friction laws and their application to seismic faulting. Ann Rev Earth Planetary Sci 26:643-696. https://doi.org/10.1146/ annurev.earth.26.1.643

Masuda K, Fujimoto K, Arai T (2002) A new gas-medium, high-pressure and high - temperature deformation apparatus at AIST, Japan. Earth Planets Space 54(11):1091-1094. https://doi.org/10.1186/BF03353307

Masuda K, Iryo K, Ogura A (2006) Internal furnace for the gas-medium high-pressure and high-temperature apparatus at the Geological Survey of Japan/AIST. Japanese J Struct Geology 49:73-76

Mizoguchi K, Takahashi M, Tanikawa W, Masuda K, Song S-R, Soh W (2008) Frictional strength of fault gouge in Taiwan Chelungpu fault obtained from TCDP Hole B. Tectonophysics 460:198-205. https://doi.org/10.1016/j.tecto. 2008.08.009

Morrow CA, Moore DE, Lockner DA (2017) Frictional strength of wet and dry montmorillonite. J Geophysical Res 122:3392-3409. https://doi.org/10.1002/ 2016JB013658

Noda H, Takahashi M (2016) Correction of output from an internal load cell in a high-pressure triaxial deformation apparatus without a split-piston. J Geological Soc Japan 122(12):653-658. https://doi.org/10.5575/geosoc.2016.0047

Passchier CW, Trouw RAJ (2005) Micro-tectonics, 2nd edn. Springer, Germany. https://doi.org/10.1007/3-540-29359-0

Rutter EH, Mainprice DH (1978) The effect of water on stress relaxation of faulted and unfaulted sandstone. Pure Appl Geophysics 116:634-654 https://doi.org/10.1007/BF00876530

Scholz CH (1998) Earthquakes and friction laws. Nature 391:37-42. https://doi.org/10.1038/34097

Scholz CH (2019) The mechanics of earthquakes and faulting, 3rd ed. Cambridge University Press, Cambridge, p 493. https://doi.org/10.1017/9781316681473

Shibazaki B, Garatani K, Iwasaki T, Tanaka A, lio Y (2008) Faulting processes controlled by the nonuniform thermal structure of the crust and uppermost mantle beneath the northeastern Japanese island arc. J Geophysical Res:113. https://doi.org/10.1029/2007JB005361

Sibson RH (1992) Implications of fault-valve behaviour for rupture nucleation and recurrence. Tectonophysics 211:283-293. https://doi.org/10.1016/00401951(92)90065-E

Takahashi M, Mizoguchi K, Kitamura K, Masuda K (2007) Effects of clay content on the frictional strength and fluid transport property of faults. J Geophysical Res 112(B8):B08206. https://doi.org/10.1029/2006JB004678

Takahashi M, Uehara S, Mizoguchi K, Shimizu I, Okazaki K, Masuda K (2011) On the transient response of serpentine (antigorite) gouge to stepwise changes in slip velocity under high-temperature conditions. J Geophysical Res 116:B10405. https://doi.org/10.1029/2010JB008062

Tullis J (2002) Deformation of granitic rocks: experimental studies and natural examples. In: Karato S, Wenk H-R (eds) Plastic deformation of minerals and rocks, reviews in mineralogy and geochemistry, vol 51. Mineralogical Society of America, Washington, DC, pp 51-95. https://doi.org/10.2138/gsrmg.51.1.51

\section{Publisher's Note}

Springer Nature remains neutral with regard to jurisdictional claims in published maps and institutional affiliations. 